\title{
The p100 coactivator is present in the nuclei of mammary epithelial cells and its abundance is increased in response to prolactin in culture and in mammary tissue during lactation
}

\author{
M K Broadhurst and T T Wheeler \\ Dairy Biotechnology, AgResearch, Private Bag 3123, Hamilton, New Zealand \\ (Requests for offprints should be addressed to T T Wheeler; Email: tom.wheeler@agresearch.co.nz)
}

\begin{abstract}
The p100 coactivator, first identified as a coactivator of the Epstein-Barr virus-encoded transcription factor, EBNA-2, in cultured cells, interacts with a number of transcription factors. However, the role of p100 in animals is unclear. We found that the abundance of p100 is closely associated with the lactating state in mammary tissue of mice and cows. Using two antibodies against independent parts of the protein, p100 immunoreactivity was localised to mammary epithelial cells, and was enriched in both nuclei and endoplasmic reticulum/organelle fractions. Stimulation of
\end{abstract}

$\beta$-casein expression in cultured mammary epithelial cells was associated with an increase in abundance of the p100 protein. The relative abundance of $\mathrm{p} 100 \mathrm{mRNA}$ was not altered in mammary tissue throughout the gestationlactation cycle, indicating that the abundance of p100 is altered by a post-transcriptional mechanism. Further work is required to clarify the function of p100 in mammary epithelial cells.

Journal of Endocrinology (2001) 171, 329-337

\section{Introduction}

The p100 coactivator was first identified in HeLa cells by its ability to interact with an Epstein-Barr virus-encoded transcription factor, Epstein-Barr virus nuclear antigen-2 (EBNA-2), and a component of the transcription initiation complex, transcription factor IIE. Coactivation was demonstrated by transfection of p100 into B lymphoblasts, where it enhanced EBNA-2 transactivational activity (Tong et al. 1995); however, its physiological role is unclear. The $\mathrm{p} 100$ protein has been shown to interact with $\mathrm{c}-\mathrm{Myb}$, a homeodomain-containing transcription factor that is thought to function in growth and differentiation (Dash et al. 1996) and Pim-1, a serine/threonine kinase found in haematopoetic tissues and testes (Leverson et al. 1998). Pim-1 has been shown to phosphorylate p100 in vitro (Leverson et al. 1998). The cDNA nucleotide and amino acid sequences have been reported for human p100 (Tong et al. 1995) as well as homologues in rat (Sakamoto et al. 1999) and a fungal pathogen, Histoplasma capsulatum (Porta et al. 1999). In the latter two species, p100 was identified by differential expression in rat aorta smooth muscle cells in response to oxidative stress, and in the fungal cells during infection of murine macrophages. Analysis of these sequences revealed four repeated domains that have similarity to staphylococcal nucleases (Callebaut \& Mornon 1997, Ponting 1997a) as well as a domain near the $\mathrm{C}$ terminus that is also found in multiple copies in the tudor protein of Drosophila, a protein that appears to function during oogenesis (Callebaut \& Mornon 1997). This similarity suggests that $\mathrm{p} 100$ shares a common protein fold with staphylococcal nucleases, although key residues required for nuclease activity are absent.

We sought to identify proteins that play a role in controlling lactation by identifying mammary nuclear proteins on one- and two-dimensional electrophoresis gels whose expression is altered between the lactating and non-lactating states (Wheeler et al. 1997a). Here, we report the identification of one of these proteins as the p100 coactivator. The p100 protein has recently been shown to be present in endoplasmic reticulum and in lipid droplets of milk-secreting cells (Keenan et al. 2000). We found that p100 is localised to both the membrane/ organelle fraction and the nuclei of mammary epithelial cells, using two antibodies raised against different parts of the protein. The increased abundance of p100 is closely associated with milk production and occurs in response to lactogenic stimuli in cultured mammary cells. Surprisingly, the increase in p100 abundance occurs without a corresponding increase in the abundance of p100 mRNA, indicating that p100 is subject to post-transcriptional regulation. Taken together, these observations show that the abundance of p100 is more closely associated with milk protein gene expression than any other nuclear 
protein thus far reported. However, function as a coactivator in mammary epithelial cells has yet to be demonstrated.

\section{Materials and Methods}

\section{Tissues and cell culture}

Bovine mammary tissue was obtained from 11 Friesian cows of various ages at defined stages of gestation and lactation as previously described (Wheeler et al. 1997a). Swiss mice at defined stages of gestation, lactation and weaning were killed by cervical dislocation and the fourth and fifth mammary glands were removed. All tissues were immediately snap-frozen in liquid nitrogen and stored at $-70{ }^{\circ} \mathrm{C}$ until analysis.

Primary cultures of mammary cells were performed on acini isolated from the glands of pregnant mice using previously described procedures (Beaton et al. 1997). Primary cells were cultured on Matrigel extracellular matrix (Becton Dickinson, Bedford, MA, USA) for 2 days in medium containing 10\% fetal calf serum (FCS), $5 \mu \mathrm{g} /$ $\mathrm{ml}$ insulin (Sigma, St Louis, MO, USA) and $3 \mu \mathrm{g} / \mathrm{ml}$ hydrocortisone, and then in the presence of these agents plus $5 \mu \mathrm{g} / \mathrm{ml}$ ovine prolactin (Sigma) to induce milk protein gene expression. The mouse mammary epithelial cell line HC11 was cultured on plastic as previously described (Ball et al. 1988) for 2 days in medium containing $10 \% \mathrm{FCS}, 5 \mu \mathrm{g} / \mathrm{ml}$ insulin and $10 \mathrm{ng} / \mathrm{ml}$ epidermal growth factor (Sigma), and then in the presence of $2 \%$ FCS and insulin plus $5 \mu \mathrm{g} / \mathrm{ml}$ ovine prolactin and $1 \mu \mathrm{M}$ dexamethasone (Sigma), to induce $\beta$-casein expression. The cells were harvested 4 days after adding prolactin.

\section{Identification of p100 by peptide microsequencing}

Mammary tissue $(150 \mathrm{~g})$ from a lactating cow was used to prepare a crude nuclear extract using the method of Dignam et al. (1983). This was further enriched for $p 100$ by heparin affinity chromatography. The proteins in this sample were subjected to electrophoresis in a $10 \%(\mathrm{w} / \mathrm{v})$ polyacrylamide-SDS gel $(50 \mu \mathrm{g}$ per well) and the gel was stained for protein with Coomassie blue. The 90-100 kDa protein band previously shown to be of higher abundance in samples from lactating cows (Wheeler et al. 1997a) was excised from 20 lanes and pooled. The amino acid sequences of three peptides derived from the protein were obtained by gas phase Edman sequencing after Lys-C digestion and reverse phase HPLC using methods that have been previously described (Wheeler et al. 1997a).

\section{Generation of p100 antibodies, Western blotting and immunohistochemistry}

A partial bovine p100 cDNA clone was obtained from a lactating mammary tissue library using human cDNA as the probe (a kind gift from $\mathrm{K}$ Carter and $\mathrm{E}$ Kieff). Full-length sequence was obtained by RT-PCR using upstream primers based on the human p100 cDNA sequence, resulting in a predicted amino acid sequence of 910 residues ( $\mathrm{T}$ T Wheeler, M K Broadhurst \& R S-F Lee, unpublished observations). Two clones were produced by RT-PCR, encoding in one case a $43 \mathrm{kDa}$ section of the bovine protein from amino acids 177-557 and in the other case a $16 \mathrm{kDa}$ section from amino acids 763-909. These were expressed in E. coli, and the recombinant proteins purified from the exclusion bodies, and used to immunise rabbits using standard procedures (Harlow \& Lane 1988, Ausubel et al. 1995).

Samples were prepared, subjected to SDS electrophoresis $(10 \mu \mathrm{g}$ per lane), and transferred to membranes using standard procedures (Ausubel et al. 1995). The membranes were stained for protein using $0 \cdot 1 \%(\mathrm{w} / \mathrm{v})$ Ponceau S (Sigma) 1\% (v/v) acetic acid to confirm equal loading, blocked in $4 \%(\mathrm{w} / \mathrm{v})$ non-fat dried milk/0.1\% Tween-20, and incubated with anti p100 IgG purified from the serum of immunised rabbits by protein A affinity chromatography (Harlow \& Lane 1988). The anti $43 \mathrm{kDa}$ and anti $16 \mathrm{kDa}$ antibodies were used at $0.66 \mu \mathrm{g} / \mathrm{ml}$ and $0 \cdot 83 \mu \mathrm{g} / \mathrm{ml}$ respectively. Immunoreactive proteins were detected using peroxidase-conjugated anti-rabbit $\operatorname{IgG}$ raised in goats (Sigma) and enhanced chemiluminescence reagents (Pierce, Rockford, IL, USA).

Immunohistochemical analysis was performed on formalin-fixed paraffin-embedded mammary tissue sliced into $5 \mu \mathrm{m}$ sections, dewaxed and peroxidase treated using previously described procedures (Wheeler et al. 1997b). The samples were then blocked using 3\% goat serum and incubated in $5 \mu \mathrm{g} / \mathrm{ml}$ anti $16 \mathrm{kDa}$ p100 rabbit $\operatorname{IgG}$ or normal rabbit IgG (Sigma) at the equivalent concentration. Secondary antibody was a $1 / 500$ dilution of peroxidase-conjugated anti rabbit $\operatorname{IgG}$ raised in goats (Sigma). Visualisaton of immunoreactivity was with 3,3'diaminobenzidine together with nickel sulphate enhancement, and the slides were counterstained using eosin.

\section{Subcellular fractionation}

Subcellular fractionation was performed essentially as previously described (Fleischer \& Kervina 1974, Wheeler et al. 1997a). Briefly, $2 \mathrm{~g}$ mammary tissue from a lactating cow was homogenised in $10 \mathrm{ml}$ of a buffer containing $10 \mathrm{mM}$ Hepes, pH 7.9, $1.5 \mathrm{mM} \mathrm{MgCl}_{2}, 10 \mathrm{mM} \mathrm{KCl}$, $0.5 \mathrm{mM}$ dithiothreitol, $1 \mathrm{mM}$ phenylmethylsulphonylfluoride, $1 \mathrm{mM}$ sodium orthovanadate, $1 \mu \mathrm{g} / \mathrm{ml}$ aprotinin, $1 \mu \mathrm{g} / \mathrm{ml}$ leupeptin and $0.7 \mu \mathrm{g} / \mathrm{ml}$ pepstatin. The nuclei and cell debris were pelleted by centrifugation at $1000 \mathrm{~g}$ for $10 \mathrm{~min}$. The supernatant was then centrifuged at $100000 \mathrm{~g}$ for $60 \mathrm{~min}$ to produce cytosolic (supernatant) and membrane plus organelle (pellet) fractions. The pellet that resulted from centrifugation at $1000 \boldsymbol{g}$ was 
resuspended in $8 \mathrm{ml}$ of a solution containing $0.25 \mathrm{M}$ sucrose, $10 \mathrm{mM}$ Hepes, $\mathrm{pH} 7 \cdot 9$ and $1 \mathrm{mM} \mathrm{MgCl}$ and centrifuged at $70000 \mathrm{~g}$ for $70 \mathrm{~min}$. The pellet from this centrifugation (nuclei) was resuspended in $2 \mathrm{ml}$ of a buffer containing $2 \cdot 2 \mathrm{M}$ sucrose, $5 \mathrm{mM}$ Hepes, $\mathrm{pH} 7.9$ and $3 \mathrm{mM} \mathrm{MgCl}_{2}$ and centrifuged at $70000 \mathrm{~g}$ for $60 \mathrm{~min}$. This pellet was resuspended in $1 \mathrm{ml}$ homogenisation buffer supplemented with Nonidet-P40 (NP-40) (BDH, Poole, Dorset, UK) to $0 \cdot 5 \%(\mathrm{v} / \mathrm{v})$, centrifuged at $4000 \mathrm{~g}$ for 5 min, washed in homogenisation buffer without NP40 and resuspended in approximately two volumes of homogenisation buffer (sucrose-purified nuclei).

A crude preparation of nuclei was made by homogenisation of the same mammary tissue in the same buffer as described above but supplemented with NP-40 to $0 \cdot 5 \%$. This was then washed in homogenisation buffer without NP-40, and resuspended in approximately 2 volumes of fresh buffer. Both sucrose-purified nuclei preparations and crude nuclei preparations were extracted for $30 \mathrm{~min}$ in $0.3 \mathrm{M} \mathrm{KCl}$ as described previously (Dignam et al. 1983).

\section{$R N A$ analysis}

RNA was isolated from $0 \cdot 2 \mathrm{~g}$ ground frozen tissue using $1.5 \mathrm{ml}$ Trizol reagent (Life Technologies, Gaithersburg, MD, USA) per sample, following the manufacturer's protocol. RNA $(10 \mu \mathrm{g})$ was subjected to electrophoresis in $1 \cdot 2 \%(\mathrm{w} / \mathrm{v})$ agarose gels containing $1 \times 3-[\mathrm{N}-$ Morpholino]propanesulphonic acid buffer and $0 \cdot 7 \%(\mathrm{v} / \mathrm{v})$ formaldehyde (Tsang et al. 1993). After capillary transfer to nylon membrane, the RNA was UV-crosslinked and stained with Methylene blue (Herrin \& Schmidt 1988) to confirm equal loading. The membranes were incubated overnight at $65{ }^{\circ} \mathrm{C}$ in phosphate buffer (Church \& Gilbert 1984) containing cDNA coding for human p100 that had been ${ }^{32} \mathrm{P}-$ labelled using the random priming method (Feinberg \& Vogelstein 1983). After hybridisation, the blots were subjected to three washes for $20 \mathrm{~min}$ each in phosphate buffer at $65{ }^{\circ} \mathrm{C}$ to remove unhybridised probe.

\section{Results}

The p100 coactivator is increased in abundance in the lactating mammary gland

Our previous investigation detected a 90-100 kDa protein in heparin-sepharose-enriched bovine mammary nuclear extracts whose abundance was increased 13-fold in mammary tissue from lactating cows (Wheeler et al. 1997a). Amino acid sequence was obtained for three peptides derived from the protein (GMWSEG, FVDGESYRAR VEK and GDVGLGLVKEGLVMVEVRK). Except for one amino acid, these sequences are identical with the deduced sequence for human p100 coactivator
(GenBank accession number U22055 (Tong et al. 1995)). Immunoblot analysis of bovine mammary homogenates using an anti human p100 antibody (a gift from E Kieff and $\mathrm{K}$ Carter) indicated a 12-fold (standard error $=4$ ) increase in abundance in lactating over non-lactating mammary tissue. Polyclonal antibodies were generated against two non-overlapping parts of bovine p100, a $43 \mathrm{kDa}$ section from the middle of the protein and a $16 \mathrm{kDa}$ section from the C-terminal end (see Materials and Methods). The specificity of these antibodies was confirmed by the inhibitory effect of preincubating the antibodies with the immunising peptide. No immunoreactivity was observed when preimmune serum or normal rabbit IgG was used (results not shown). Western blot analysis with these antibodies resulted in a strongly immunoreactive $100 \mathrm{kDa}$ band in both bovine and murine mammary tissue that was present at barely detectable levels in non-lactating animals (Fig. 1). These results confirmed that the p100 transcriptional coactivator was present in the mammary gland and was increased in abundance in lactating compared with non-lactating animals.

In order to determine if changes in p100 immunoreactivity are coincident with critical events in the gestationlactation cycle, tissue was obtained from mice at defined stages of the cycle. The p100 immunoreactivity was increased slightly during the final 3 days of pregnancy, then increased markedly on the day of parturition (day 19 of pregnancy) and remained elevated during lactation (Fig. 2 ). This result was consistent for three mice at each time-point (results not shown). A marked decrease in p100 immunoreactivity was observed during the first 2 days of mammary involution, after pups were removed from 10 days lactating mice (Fig. 2). This result was consistent for two mice at each time-point (results not shown). Together, these results showed that changes in the abundance of p100 in the mammary gland were closely associated with lactogenesis and mammary involution.

\section{Subcellular localisation of $p 100$}

We performed subcellular fractionation and immunohistochemical analyses on mammary tissue to determine in which cells p100 is present and, within these cells, where p100 is localised. Analysis of subcellular fractions of bovine mammary tissue showed substantial p100 immunoreactivity in extracts of a crude nuclei preparation as well as extracts of sucrose density-purified nuclei from bovine mammary tissue (Fig. 3). In addition, significant p100 immunoreactivity was observed in the membrane/ organelle fraction. Immunoreactivity against the endoplasmic reticulum protein, glucose-regulated protein $78 \mathrm{kDa}$, was confined to the membrane/organelle fraction. Immunoreactivity against the transcription factor $\mathrm{Sp} 1$ was present in both nuclear extract preparations, as well as faintly in the cytosol (Fig. 3), indicating a minor degree of contamination of nuclear proteins in the cytosol. 


\section{Cow Mouse}

\section{3 kDa p100 $66-$} antibody

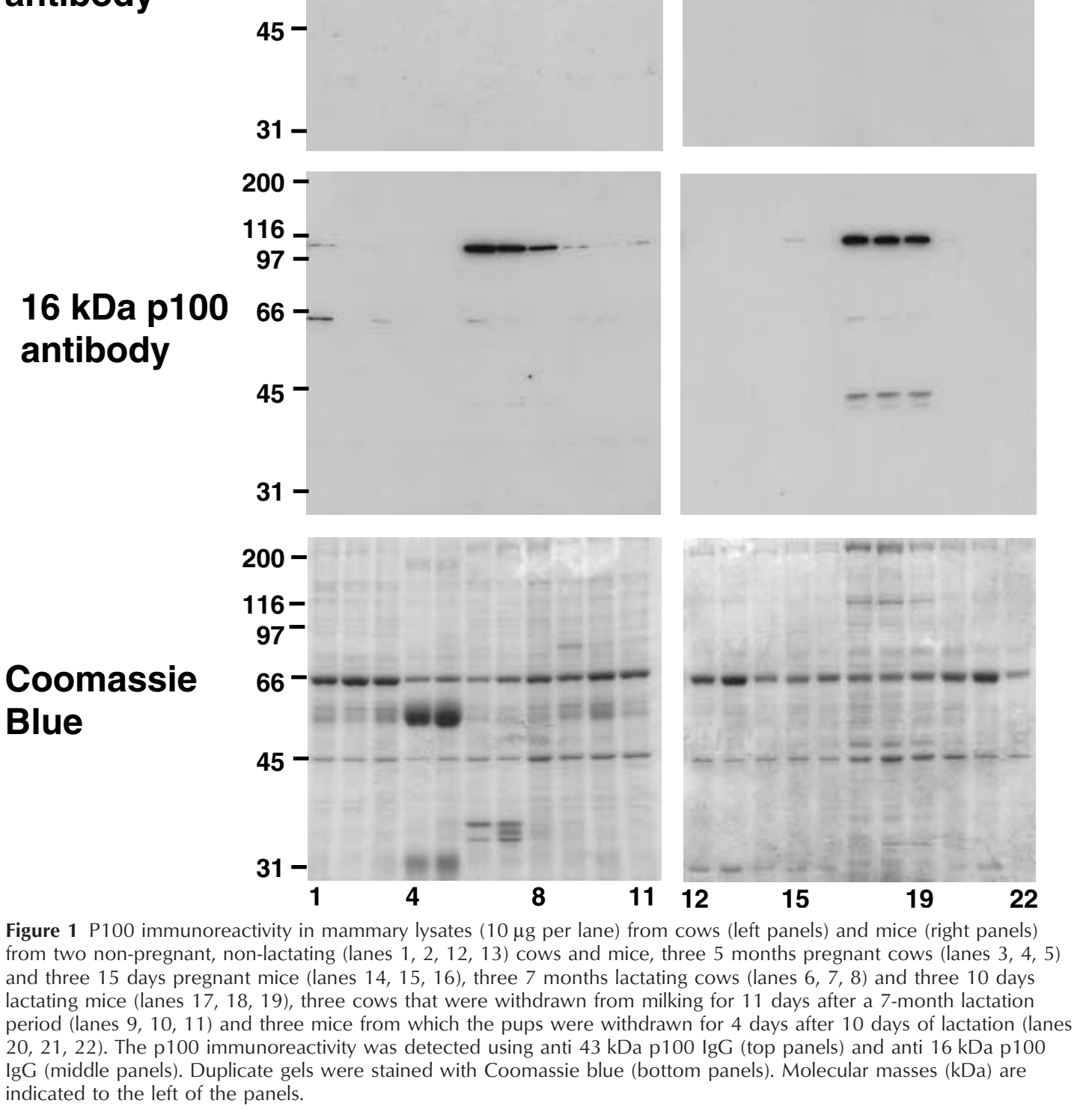




\section{Pregnant Lactating}

Invol

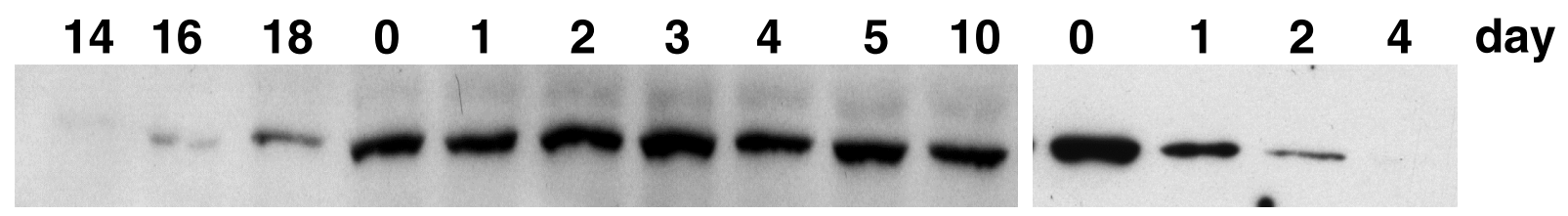

Figure 2 P100 immunoreactivity in mouse mammary tissue throughout the gestation-lactation cycle. Mammary lysates were analysed from a series of mice at the indicated number of days after mating (Pregnant), after giving birth (Lactating) and from 10 days lactating mice from which pups were removed for the indicated number of days (Invol). A rabbit polyclonal anti human p100 antibody was used.

$\underline{\text { WB }}$

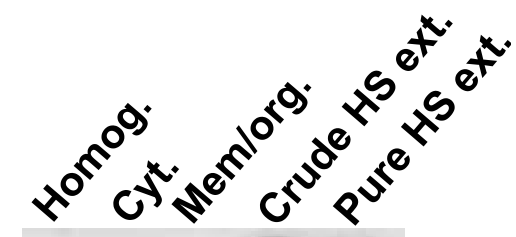

43 kDa p100

\section{6 kDa p100}

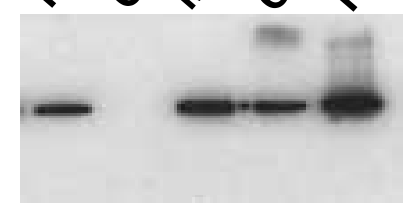

\section{GRP78}

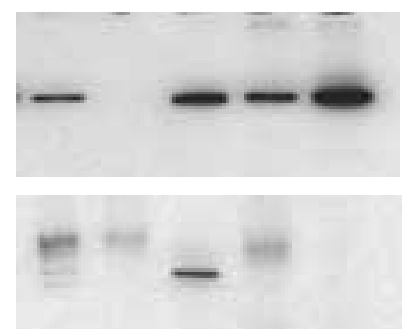

Sp1

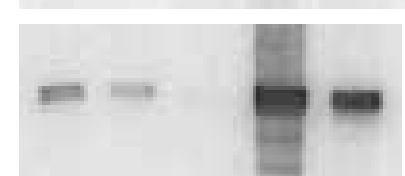

\section{$\begin{array}{lllll}1 & 2 & 3 & 4 & 5\end{array}$}

Figure 3 Immunoblotting of subcellular fractions for p100. Mammary homogenate (Homog.) from a lactating cow (lane 1) was subjected to differential centrifugation as described in the Materials and Methods section to isolate a high speed supernatant (cytosol (Cyt.); lane 2), medium-speed pellet (membrane/organelles (Mem/org.); lane 3), and a low-speed crude nuclei pellet. High salt (HS) extracts (ext.) were prepared from crude (lane 4) and purified (lane 5) nuclei, in the latter case after pelleting the crude nuclear prep through a sucrose cushion. Equal quantities of protein $(10 \mu \mathrm{g})$ were subjected to Western blot (WB) immunoblotting using anti $43 \mathrm{kDa}$ p100 IgG (top panel), anti 16 kDa p100 IgG (second panel), anti GRP78 IgG raised in goats (Santa Cruz Biotechnology, Santa Cruz, CA, USA; catalogue number sc-1050) (third panel), and anti Sp1 IgG raised in rabbits (Santa Cruz Biotechnology; catalogue number sc-59) (bottom panel). The diffuse slower mobility band in the third panel was also observed when the primary antibody was omitted.
These results showed that p100 immunoreactivity was present in both nuclei and membrane/organelle fractions and that this was not due to cross contamination of the fractions.

Immunohistochemical analysis of mammary tissue taken from lactating cows and mice localised p100 to the secretory epithelial cells (Fig. 4). No immunoreactivity was observed in stromal cells or areas containing predominantly connective tissue. Thus, the mammary epithelial cells appeared to be the only cell type in the mammary gland that contained a high abundance of $\mathrm{p} 100$. For both species, most, but not all of the secretory cells were immunoreactive. The p100 immunoreactivity was localised to the nuclei (arrows in Fig. 4). This apparent contradiction between the subcellular fractionation and immunohistochemistry was not investigated in depth; however, it could conceivably be the result of changes in p100 distribution during tissue disruption or differences between the techniques in sensitivity of detection. A low level of extranuclear staining cannot be ruled out from our immunohistochemical analysis. Exclusively nuclear localisation of p100 was reported in Cos cells and cultured fibroblasts (Tong et al. 1995). However, a recent report localised p100 immunoreactivity predominantly to the extranuclear areas of cultured bovine mammary cells (Keenan et al. 2000). A good explanation for the lack of consistency between the studies requires further investigation.

Changes in 100 abundance in response to lactogenic signals

It is possible that the increase in p100 abundance at the onset of lactation occurs through response to lactogenic hormones. To investigate this, p100 abundance was measured in primary cultures of 15 days pregnant mouse mammary cells and the mouse mammary cell line HC11. Addition of prolactin and dexamethasone to the culture medium of HC11 cells, and the addition of prolactin to the primary cells, resulted in a significant increase in p100 abundance (Fig. 5) as well as synthesis of $\beta$-casein (result for primary cells not shown). This indicated that $\mathrm{p} 100$ 


\section{Cow}
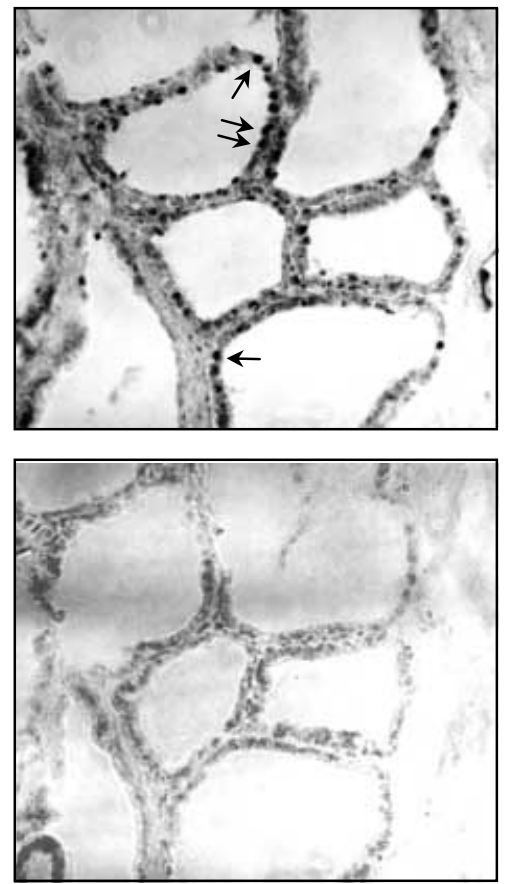

Mouse
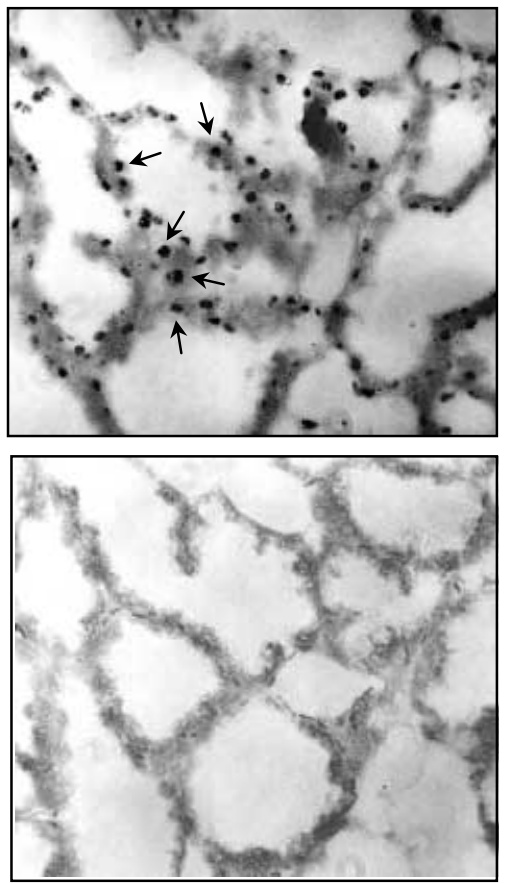

Figure 4 Immunohistochemistical analysis of mammary tissue. Mammary tissue was obtained from a lactating cow 6 months after giving birth (two panels to the left) and a 10 days lactating mouse (two panels to the right). These were subjected to immunohistochemical analysis using anti $16 \mathrm{kDa}$ p100 IgG (upper two panels) or normal rabbit IgG (lower two panels). Immunoreactivity was detected using peroxidaseconjugated anti-rabbit IgG. The signal was visualised with diaminobenzidine. The tissues were counterstained with eosin and photographed at $\times 400$ magnification. Arrows indicate examples of perialveolar nuclear immunostaining.

abundance was increased in mammary cells in response to these lactogenic hormones.

\section{Abundance of $p 100 \mathrm{mRNA}$ in the mammary gland}

The increase in p100 protein abundance may be the consequence of an increase in p100 gene transcription. To address this possibility, we determined the relative abundance of p100 mRNA in the mammary gland. Mammary RNA was isolated from the same series of cows and mice as shown in Fig. 1 as well as HC11 cells cultured in the presence or absence of prolactin as described above, and analysed by Northern blotting using human p100 cDNA as a probe. For both bovine and murine RNA, a single band was observed of similar size to the $4 \mathrm{~kb}$ mRNA previously reported for human p100 (Tong et al. 1995). Surprisingly, the relative abundance of p100 mRNA was not significantly altered either in tissues between the lactation states (Fig. 6) or in the cultured cells in response to lactogenic hormones (results not shown), indicating that changes in p100 protein abundance were not the consequence of transcriptional regulation of the p100 gene.

\section{Discussion}

The molecular mechanism controlling milk protein gene expression in lactating mammary glands is not clearly understood. A number of hormones and factors influence milk protein gene expression in mammary epithelial cells, the best understood being prolactin and glucocorticoids (Neville \& Daniel 1987). These signals are likely to be mediated through transcription factors, which act on the promoters of the milk protein genes. Several transcription factors have been studied in this regard, including Stat5, glucocorticoid receptor, NFKB, NF-1, and C/EBP (for examples see Li \& Rosen 1995, Raught et al. 1995, Liu et al. 1996, Stoecklin et al. 1996, Lechner et al. 1997, Geymeyer \& Doppler 2000); however, a clear overall picture of how transcriptional control of milk protein genes is achieved throughout the gestation-lactation cycle is yet to emerge. It is possible that additional transcriptional activators or coactivators are involved that have not yet been studied in this context. The abundance of mammary p100 during the gestation-lactation cycle is specifically and closely associated with lactation, and is therefore 


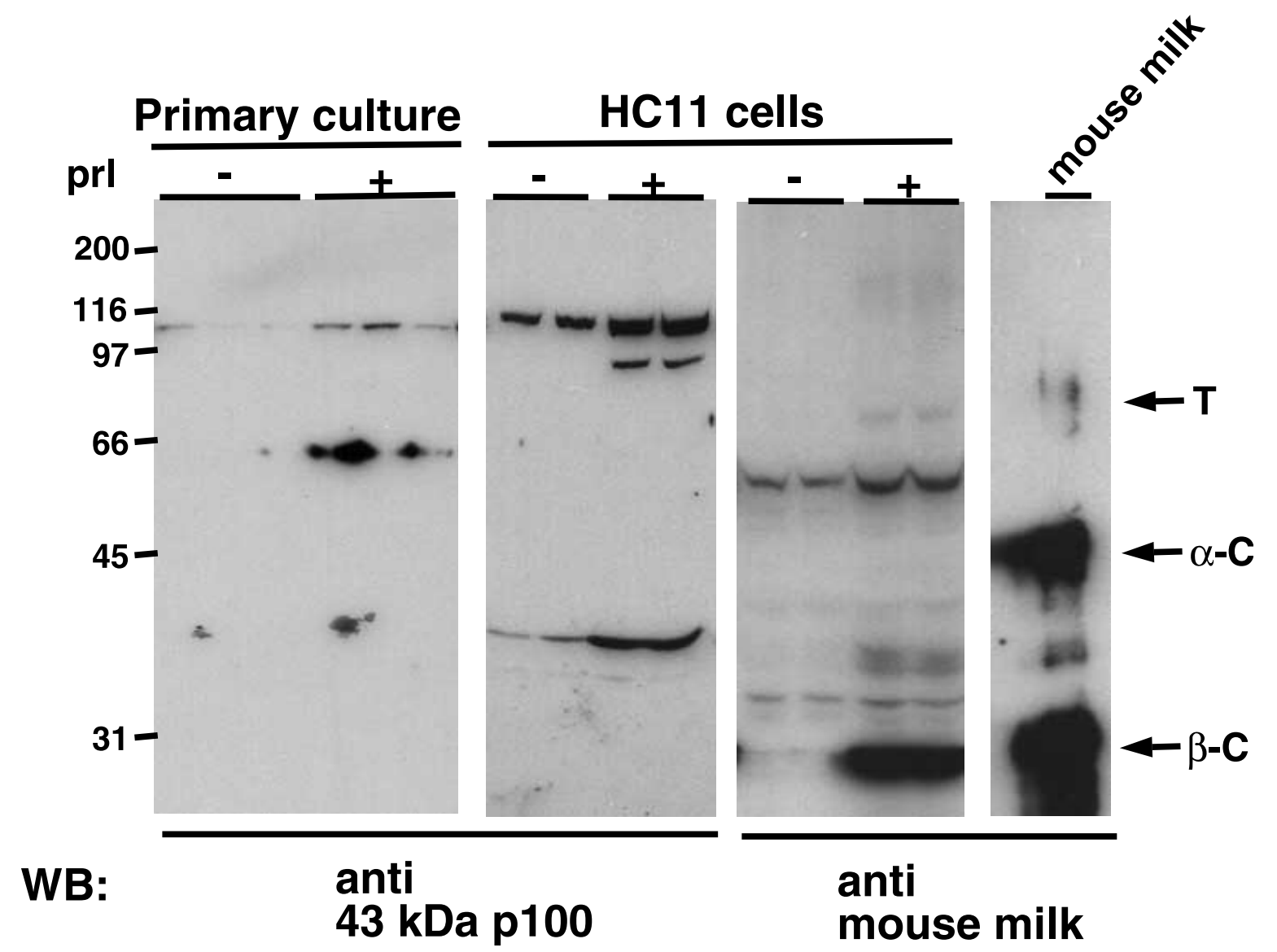

Figure 5 P100 immunoreactivity in cultured mammary cells in response to prolactin (prl). Primary cultures of mouse mammary cells (triplicates per condition) and HC11 cells (duplicates per condition) were cultured and exposed to prolactin (primary cells) or prolactin plus dexamethasone ( $\mathrm{HC} 11$ cells) as described in the Materials and Methods. Cell lysates were subjected to Western blot (WB) analysis using anti 43 kDa p100 lgG (first and second panels) or anti mouse milk antibodies (third panel). A sample of mouse milk was subjected to Western blotting using anti mouse milk rabbit antiserum (fourth panel). The position of the major mouse milk proteins, transferrin $(T), \alpha$-casein $(\alpha-C)$ and $\beta$-casein $(\beta-C)$ are indicated.

unique compared with other transcription factors. In addition, the increased p100 abundance during lactation appears to be a common feature among mammals, as it occurs in the bovine, murine and ovine mammary glands, and is increased in the late phase of lactation in at least one marsupial (results not shown). Furthermore, the abundance of $\mathrm{p} 100$ is increased in response to the presence of the lactogenic hormone, prolactin, in cultured mammary cells.

The physiological role of $\mathrm{p} 100$ is unclear. Transfection of p100 into B-lymphoblasts results in a twofold coactivation of EBNA-2 activity (Tong et al. 1995); however, the amino acid sequence of p100 shows no homology to the $\mathrm{CBP} / \mathrm{P} 300$ or steroid receptor coactivator (SRC) classes of coactivators. Homologues of $\mathrm{p} 100$ protein exist in a number of species, and these have been implicated in a variety of physiological processes. Human p100 in HeLa cells has been implicated in Epstein-Barr virus-host cell interaction (Tong et al. 1995), a p100 homologue in the fungus Histoplasma capsulatum has been implicated in infection of macrophages (Porta et al. 1999), and a rat homologue is increased in vascular smooth muscle cells in response to oxidative stress (Sakamoto et al. 1999). In addition, the p100 interaction with c-myb raises the possibility that it is involved in growth and differentiation (Leverson et al. 1998) and p100 has recently been associated with milk lipid transport and secretion (Keenan et al. 2000). The relatively high degree of amino acid sequence conservation in diverse organisms suggests a fundamental role in cell biology that is not limited to the mammary gland. However, the data currently available are not sufficient to provide a definitive conclusion as to what this role is.

It is conceivable that $\mathrm{p} 100$ functions in the nucleus of mammary epithelial cells to control expression of the milk protein genes. Its coactivation activity in transfected 


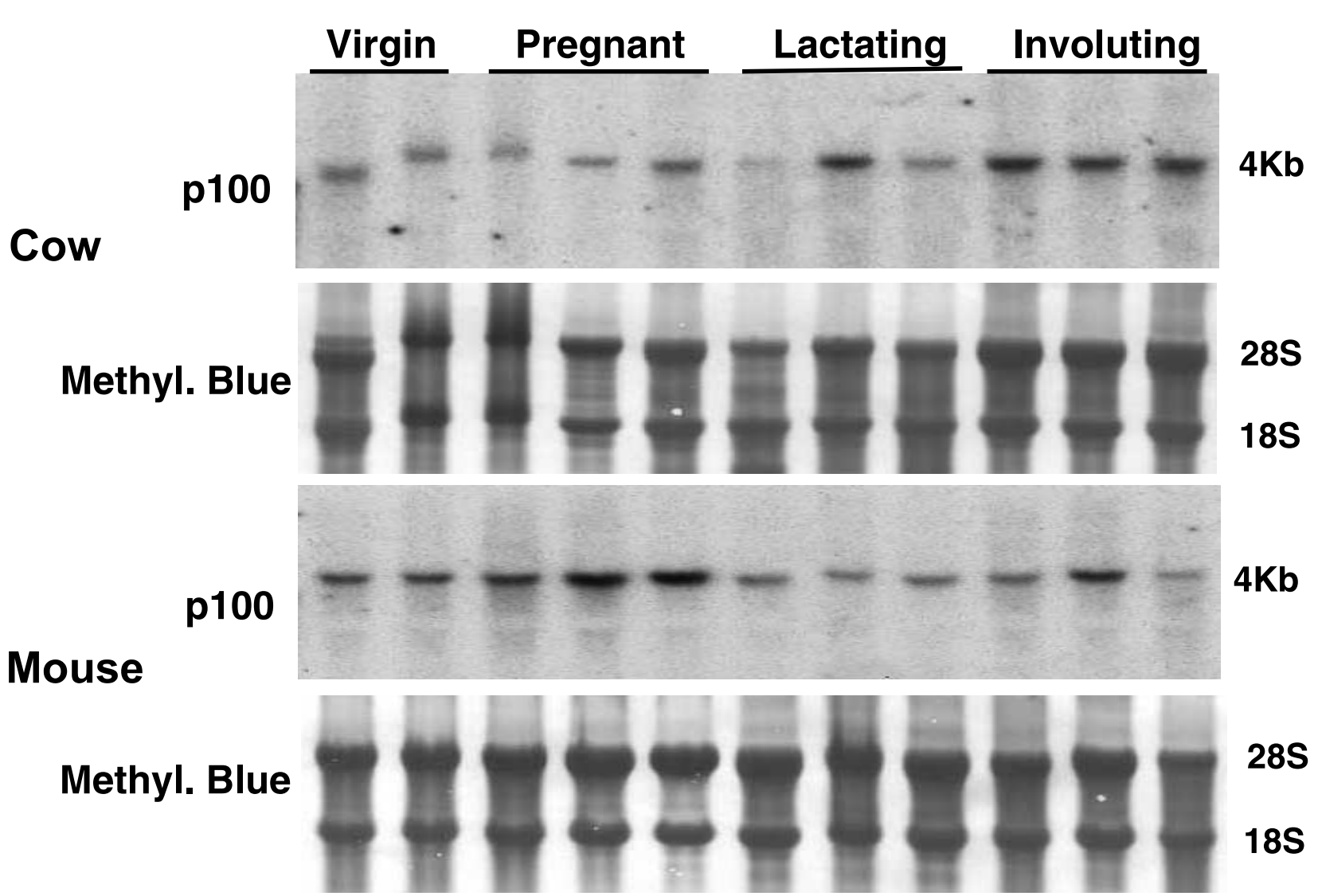

Figure 6 Northern blot analysis of mammary RNA. RNA $(10 \mu \mathrm{g})$ from the same series of 11 cows (upper two panels) and 11 mice (lower two panels) as analysed in Fig. 1 was analysed. The p100 mRNA was visualised by hybridisation with human p100 cDNA (first and third panels). The total RNA was visualised after transfer to the membrane by staining with methylene (Methyl.) blue (second and fourth panels).

lymphoblasts, interaction with other transcription factors, nuclear localisation and its increased abundance during lactation are consistent with such a function. Furthermore, the structural similarity of p100 with staphylococcal nucleases (Callebaut \& Mornon 1997, Ponting 1997a), and the presence of a Tudor domain within p100 are consistent with binding to nucleic acids (Ponting 1997b), although p100 binding to DNA or RNA has not been reported. On the other hand, localisation to the membrane/organelle compartment and a recent report localising p100 to the endoplasmic reticulum and lipid droplets (Keenan et al. 2000) suggest another role. Modulation of p100 activity in mammary glands appears to occur, at least in part, through post-transcriptional control of expression, perhaps at the level of translation or protein stability/turnover. The ability of the kinase, Pim-1, to phosphorylate 100 in vitro suggests a possible means of modulating p100 activity. Further experimentation is required to confirm these possibilities and to shed light on p100 function in the mammary gland. Nevertheless, the data presented here open up a new avenue for investigating the molecular mechanisms controlling milk production in mammary epithelial cells.

\section{Acknowledgements}

We thank K Carter and E Kieff, Department of Microbiology and Molecular Genetics, Harvard University, Brigham and Women's Hospital, Boston, for the gift of human p100 cDNA and antibody, R Broadhurst for the mouse tissues, B Bennet for his gift of the anti mouse milk antibody, A Molenaar for sheep mammary samples and C McMahon for help with the immunohistochemistry procedure.

\section{References}

Ausubel FM, Brent R, Kingston RE, Moore D, Seidman JG, Smith JA \& Struel JA (Eds) 1995 Current Protocols in Molecular Biology. New York: John Wiley \& Sons. 
Ball R, Friis RR, Schoenenberger CA, Doppler W \& Groner B 1988 Prolactin regulation of $\beta$-casein gene expression and of a cytosolic $120 \mathrm{kd}$ protein in a cloned mouse mammary epithelial cell line. EMBO Journal 7 2089-2095.

Beaton A, Wilkins RJ \& Wheeler TT 1997 Lactation-associated and prolactin-responsive changes in protein synthesis in mouse mammary cells. Tissue and Cell 29 509-516.

Callebaut I \& Mornon JP 1997 The human EBNA-2 coactivator p100: multidomain organization and relationship to the staphylococcal nuclease fold and to the tudor protein involved in Drosophila melanogaster development. Biochemical Journal 321 125-132.

Church GM \& Gilbert W 1984 Genomic sequencing. PNAS 81 1991-1995.

Dash AB, Orrico FC \& Ness SA 1996 The EVES motif mediates both intermolecular and intramolecular regulation of $\mathrm{c}-\mathrm{Myb}$. Genes and Development 10 1858-1869.

Dignam JD, Lebovitz RM \& Roeder RG 1983 Accurate transcription initiation by RNA polymerase II in a soluble extract from isolated mammalian nuclei. Nucleic Acids Research 11 1475-1489.

Feinberg AP \& Vogelstein B 1983 A technique for radiolabelling DNA restriction endonuclease fragments to high specific activity. Analytical Biochemistry 132 6-13.

Fleischer S \& Kervina M 1974 Subcellular fractionation of rat liver. Methods in Enzymology 31 6-41.

Geymeyer S \& Doppler W 2000 Activation of NFkB p50/p65 is regulated in the developing mammary gland and inhibits STAT5mediated $\beta$-casein gene expression. FASEB Journal 14 1159-1170.

Harlow E \& Lane D 1988 Antibodies: A Laboratory Manual. Cold Spring Harbor Laboratories: New York.

Herrin DL \& Schmidt GW 1988 Rapid, reversible staining of Northern blots prior to hybridisation. BioTechniques 6 96-199.

Keenan TW, Winter S, Rackwitz H-R \& Heid HW 2000 Nuclear coactivator protein $\mathrm{p} 100$ is present in endoplasmic reticulum and lipid droplets of milk producing cells. Biochimica et Biophysica Acta 1519 84-90.

Lechner J, Welter T, Tomasi JK, Bruno P \& Cairns C 1997 Promoter-dependent synergy between glucocorticoid receptor and Stat 5 in the activation of $\beta$-casein gene transcription. Journal of Biological Chemistry 272 20954-20960.

Leverson JD, Koskinen PJ, Orrico FC, Rainio E-M, Jalkanen KJ, Dash AB, Eisenman RN \& Ness SA 1998 Pim-1 kinase and p100 cooperate to enhance c-Myb activity. Molecular Cell 2 417-425.

Li S \& Rosen JM 1995 Nuclear factor I and mammary gland factor (STAT5) play a critical role in regulating rat whey acidic protein gene expression in transgenic mice. Molecular and Cellular Biology 15 2063-2070.
Liu X, Robinson GW \& Hennighausen L 1996 Activation of Stat5a and Sta5b by tyrosine phosphorylation is tightly linked to mammary gland differentiation. Molecular Endocrinology 10 1496-1506.

Neville MC \& Daniel CW (Eds) 1987 The Mammary Gland: Development, Regulation, and Function. New York: Plenum Press.

Ponting CP 1997a P100, a transcriptional coactivator, is a human homologue of staphylococcal nuclease. Protein Science 6 459-463.

Ponting CP $1997 b$ Tudor domains in proteins that interact with RNA. Trends in Biochemical Sciences 253 51-52.

Porta A, Colonna-Romano S, Callebaut I, Franco A, Marzullo L, Kobayashi GS \& Maresca B 1999 An homologue of the human $100 \mathrm{kDa}$ protein (p100) is differentially expressed by Histoplasma capsulatum during infection of murine macrophages. Biochemical and Biophysical Research Communications 254 605-613.

Raught B, Liao WS-L \& Rosen JM 1995 Developmentally and hormonally regulated CCAAT/enhancer-binding protein isoforms influence $\beta$-casein expression. Molecular Endocrinology 9 1223-1232.

Sakamoto K, Yamasaki Y, Kaneto H, Fujitani Y, Matsuoka T, Yoshioka R, Tagawa T, Matshisa M, Kajimoto Y \& Hori M 1999 Identification of oxidative stress-regulated genes in aortic smooth muscle cells by suppression subtractive hybridisation. FEBS Letters 461 47-51.

Stoecklin E, Wissler M, Gouilleux F \& Groner B 1996 Functional interactions between Stat 5 and the glucocorticoid receptor. Nature $383726-728$.

Tong X, Drampkin R, Yalamanchili R, Mosialos G \& Kieff E 1995 The Epstein-Barr virus nuclear protein 2 acidic domain forms a complex with a novel cellular coactivator that can interact with TFIIE. Molecular and Cellular Biology 15 4735-4744.

Tsang SS, Yin X, Guzzu-Arkuran C, Jones VS \& Davison AJ 1993 Loss of resolution in gel electrophoresis of RNA: a problem associated with the presence of formaldehyde gradients. BioTechniques 14 380-381.

Wheeler TT, Broadhurst MK, Rajan GH \& Wilkins RJ 1997a Differences in the abundance of nuclear proteins in the bovine mammary gland throughout the lactation and gestation cycles. Journal of Dairy Science 80 2011-2019.

Wheeler TT, Kuys YM, Broadhurst MK \& Molenaar AJ $1997 b$ Mammary Stat5 abundance and activity are not altered with lactation state in cows. Molecular and Cellular Endocrinology 133 141-149.

Received 4 June 2001

Accepted 9 July 2001 